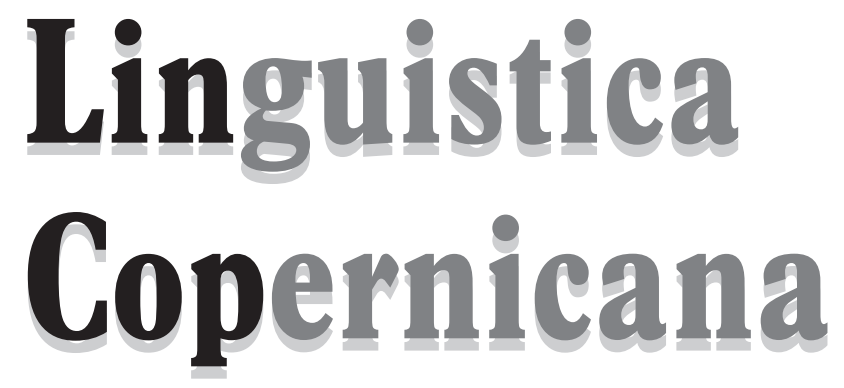

$1(7) / 2012$

WYDAWNICTWO NAUKOWE
UNIWERSytetu MIKOLAJa KOPERNIKA 
REDAKTOR NACZELnY: Maciej Grochowski

Rada Redakcyjna: Ireneusz Bobrowski (Kraków), Andrzej Bogusławski (Warszawa), Gerd Hentschel (Niemcy, Oldenburg), Axel Holvoet (Litwa, Wilno), Krystyna Kleszczowa (Katowice), Roman Laskowski (Kraków), Jarmila Panevová (Czechy, Praha), Jens Nørgård-Sørensen (Dania, Kopenhaga), Zuzanna Topolińska (Macedonia, Skopje), Daniel Weiss (Szwajcaria, Zurich), Anna Wierzbicka (Australia, Canberra)

Kole gi u m R e D K C Y J e: Maciej Grochowski, Krystyna Kallas, Irena Sawicka, Piotr Stalmaszczyk

S E K R ETA R Z R E D A K C I: Iwona Kaproń-Charzyńska

A D R E S R E D A K C J I: Instytut Języka Polskiego UMK, 87-100 Toruń, ul. Fosa Staromiejska 3, e-mail: lincop@umk.pl,www.linguistica.umk.pl

OKŁ A D K A: Monika Pest

(C) Copyright by Wydawnictwo Naukowe Uniwersytetu Mikołaja Kopernika

Toruń 2012

ISSN 2080-1068

Wersją pierwotną (referencyjną) czasopisma jest wersja papierowa.

WYDAWNICTWO NAUKOWE UNIWERSYTETU MIKOEAJA KOPERNIKA

Redakcja: ul. Gagarina 5, 87-100 Toruń

tel. (56) 6114295 , tel./fax 6114705

e-mail: wydawnictwo@umk.pl

Dystrybucja: ul. Reja 25, 87-100 Toruń

tel./fax (56) 61142 38, e-mail: books@umk.pl

www.wydawnictwoumk.pl

Druk: Wydawnictwo Naukowe UMK 


\title{
Magdalena Danielewiczowa
}

\section{Czy aby Maciej mi przytaknie? O statusie $a b y$ w pytaniach rozstrzygnięcia*}

\author{
Maciejowi Grochowskiemu \\ z najlepszymi życzeniami \\ kolejnych owocnych lat pracy
}

Słow a klucze: semantyka, jednostka języka, pytania rozstrzygnięcia, metaoperatory, partykuły

W tym krótkim artykule chciałabym się zająć wyrażeniem $a b y$. Z co najmniej czterech względów nie powinno to być całkiem obojętne lub zgoła przykre dla Pana Profesora Grochowskiego: po pierwsze dlatego, że aby wywołuje skojarzenia z bliskim Jego sercu pojęciem celu; po drugie, wybranym strukturom składniowym zorganizowanym wokół tego elementu poświęcił On pokaźny fragment w Gramatyce współczesnego języka polskiego (zob. Grochowski 1984); po trzecie, przynajmniej w niektórych swoich wcieleniach aby świetnie nadaje się do tego, by rozważać je na tle tzw. wyrażeń funkcyjnych (które to hasło natychmiast kieruje myśl w stronę Macieja Grochowskiego) i pytać o charakterystykę tego wyrażenia jako części mowy (czy

* Myśli zawarte w tym artykule zostały przedstawione w czasie sympozjum zorganizowanego w listopadzie 2012 roku w Toruniu dla uczczenia czterdziestolecia pracy naukowej Profesora Macieja Grochowskiego. 
jest to mianowicie spójnik, partykuła, operator trybu, czy jeszcze coś innego?); po czwarte, w końcu problem, którego chcę dotknąć, ma bezpośredni związek ze sprawą delimitacji jednostek języka podporządkowaną wyłonieniu z potoku mowy bytów konkretnych, co stanowi jeden z motywów przewodnich naukowej działalności Profesora Grochowskiego.

Tytułowemu wyrażeniu można by z powodzeniem poświęcić sporych rozmiarów monografię, gdyby oczywiście chcieć uwzględnić i w szczegółach opisać wszystkie typy kontekstów, w jakich może się ono pojawiać, gdyby chcieć ponadto zestawić je z ażeby, żeby, iżby, a przede wszystkim z prostym $b y$, zmierzając $\mathrm{w}$ ten sposób do wyodrębnienia rzeczywistych elementów bazy językowej polszczyzny, a następnie do ich charakterystyki składniowej, semantycznej i pragmatycznej. Opracowanie takie, jak sądzę, dostarczyłoby sporej wiedzy nie tylko o rozmaitych uwikłaniach samego kształtu $a b y$, lecz także zmusiłoby do rozstrzygnięcia zasadniczych problemów metodologicznych, przede wszystkim z pogranicza semantyki i składni. Może rzeczywiście taką monografię warto byłoby napisać.

Tymczasem jednak chcę zarysować możliwe odpowiedzi na jedno tylko pytanie związane z wystąpieniami wyrażenia $a b y$. Jak za chwilę pokażę, już ta jedna kwestia wikła tego, kto zechce się nią zająć, w zasadnicze problemy i pociąga za sobą pytania następne. Będzie mi chodziło mianowicie o status aby w zdaniach takich, jak przytoczone w tytule tego artykułu, a więc w pytaniach rozstrzygnięcia. Przywołam dwa podobne do tamtego przykłady:

(1) Czy aby wytaczyteś żelazko?

(2) Czy aby nie zapomnieliście o zebraniu?

Kiedy mówię o statusie aby w tego rodzaju kontekstach, to chodzi mi o ustalenie, czy jest to niezależny od innych, wchodzący w układy proporcjonalne bilateralny element leksykonu współczesnej polszczyzny, czy też wyrażenie to ma inny charakter. Przy pozytywnym spełnieniu pierwszego członu wskazanej alternatywy można dalej pytać o to, jakiego rodzaju byłaby to jednostka.

Słowniki języka polskiego interesujący mnie problem rozstrzygają zasadniczo w dwojaki sposób. W opracowaniach starszych (pod redakcją W. Doroszewskiego i M. Szymczaka) wskazane wyrażenie traktowane jest jako nieodrywalne od pytajnika czy i łącznie z nim tworzące coś w rodzaju fra- 
zeologizmu. Frazeologizm ten przypisany został w obu wspomnianych leksykonach do kompleksu kontekstów odpowiadających w intencji redaktorów użyciom ,partykuły o znaczeniu ograniczającym”, a jego sens przybliża fraza czy tylko (zob. SJPDor/I: 18). Na marginesie warto powiedzieć, że również w niektórych słownikach frazeologicznych konstrukcja $c z y$ aby_odnotowywana jest jako leksykalna całość (zob. np. Müldner-Nieckowski 2003).

Słownik wspótczesnego języka polskiego pod redakcją B. Dunaja pytania rozstrzygnięcia z udziałem aby całkowicie pomija, zarówno jako przedmiot opisu, jak i materiał przykładowy, a obok spójnika o tym kształcie wyróżnia jeszcze homonimiczny względem tamtego modalizator, występujący np. w zdaniach Aby do wiosny, Aby tylko zdqżyć na ostatni pociag, za pomocą którego mówiący ma sygnalizować, że treść zdania jest życzeniem (por. SWJP: 2).

W Innym słowniku języka polskiego pod redakcją M. Bańki (ISJP /I: 4-5) użycia pytajne, o które tu przede wszystkim chodzi, zostały opisane jako aktualizacja wieloznacznej, dającej się odseparować od pytania partykuły $a b y$, która w innej grupie kontekstów może zrealizować inny sens. Partykuła ta jest w omawianym leksykonie ujmowana jako homonimiczna względem równie wieloznacznego spójnika. Redaktorzy wyróżnili przy tym dwa różne znaczenia takiego aby partykułowego uwikłanego w pytania rozstrzygnięcia. Cyt.:

7 W pytaniach, na które można odpowiedzieć „tak” lub „nie”, słowa aby używamy, kiedy chcemy wyrazić wątpliwość co do treści pytania i swoje oczekiwania wobec niej. Jeśli zdanie nie jest zaprzeczone, chcemy, aby jego treść była prawdziwa; jeśli zdanie jest zaprzeczone - chcemy, aby była fałszywa: $C z y$ dziecko aby się nie przeziębiło?, Czy ta ryba jest aby na oleju?

8 Słowa aby używamy w zdaniach pytajnych, zwracając się do kogoś, komu chcemy dać do zrozumienia, że zachował się niewłaściwie: Czy to aby nie za późna pora na wizytę?

Pomijając sprawę, która jest głównym przedmiotem tego artykułu, trzeba zauważyć, że mamy tu do czynienia z klasycznym błędem rozmnożenia znaczeń, mającym swe źródło w dwóch czynnikach: po pierwsze, w braku odpowiedniej semantycznej generalizacji struktur z udziałem $a b y$, po drugie w zmieszaniu ich komponentów stricte znaczeniowych z własnościami prag- 
matycznymi. Glosa zawarta w punkcie $\mathbf{8}$ rozważanego artykułu hasłowego została dodana ad hoc w związku z pragmatycznym kontekstem, który najwyraźniej przyszedł redaktorom aktualnie do głowy. Na tej samej zasadzie można by w kolejnych punktach dodać charakterystyki następujące:

$9 \mathrm{~W}$ pytaniach rozstrzygnięcia słowa aby używamy, żeby wyrazić komuś naszą o niego troskę: Czy aby nie za bardzo się przemęczasz?, Czy aby na pewno dobrze pani spata?

10 Słowa aby używamy w pytaniach grzecznościowych, sygnalizując gotowość do odstąienia na znak odbiorcy od planowanych działań : Czy aby nie przeszkadzam?

Zabawę tę można by oczywiście kontynuować. Z metodologicznego punktu widzenia postępowanie takie jest niewłaściwe.

Notabene konieczność dodania punktu $\mathbf{8}$ w charakterystyce aby zaproponowanej przez Inny słownik języka polskiego pojawiła się, jak sądzę, jako odpowiedź na brak dostatecznego uogólnienia znaczenia 7. Rzecz w tym, że w użytym z przyganą pytaniu Czy to aby nie za późna pora na wizyte?, które obok dwóch innych przykładów przykuło uwagę autora hasła, nijak nie można się dopatrzyć ekspresji wątpliwości czy oczekiwania w stosunku do treści tegoż pytania. Na marginesie powiem, że zupełnie niepotrzebnie skomentowane zostały pod kątem znaczenia osobno zdania z pozytywnym i osobno z negatywnym datum quaestionis. Tu również daje o sobie znać niedostatek generalizacji.

Inna sprawa, że - jak pokazał Andrzej Bogusławski (2000: 55-57) - w pytaniach pozytywnych i negatywnych z udziałem aby niejednakowo wyodrębniają się podsegmenty, które podlegają prawidłowej reiteracji. I tak w wypadku konstrukcji z przeczeniem powtórzenie cząstki nie jest obligatoryjne, podczas gdy aby nie musi być reiterowane, ale jeśli już jest, to z towarzyszeniem poprzedzającej je partykuły $c z y$, por. np.: $+C z y$ on tego aby nie sprzedat $i$ nie uciekt?, a z drugiej strony $+C z y$ on tego aby nie sprzedat $i$ czy aby nie uciekt? vs. ${ }^{*}$ Czy on tego aby nie sprzedat $i$ aby nie uciekt?, ${ }^{*} C z y$ on tego aby nie sprzedat i uciekt? Jeśli zaś chodzi o wyrażenie czy_aby_ (bez negacji), to może być ono powtarzane wyłącznie jako całość, np. $+C z y$ on to aby sprzedat $i$ czy aby zarobit pare groszy? vs. ${ }^{*} C z y$ on to aby sprzedat $i$ aby zarobit pare groszy? 
Różnice w podatności na iterację członów pytań pozytywnych i negatywnych zawierających element aby nie muszą jeszcze świadczyć o tym, że pytaniom tym przysługują niezależne reprezentacje semantyczne.

A. Bogusławski nie zastanawiał się nad znaczeniem interesujących mnie tu struktur. W przywołanym artykule określał je z grubsza jako wyrażenia przekazujące „obawę na nie” czy troskę mówiącego o zachodzenie odpowiednich stanów rzeczy i zwracał uwagę na to, że pozostają w wyraźnym kontraście ze zobiektywizowanymi pytaniami niezawierającymi elementu $a b y$.

Zanim przejdę wreszcie do rozważenia na własny użytek tytułowej kwestii związanej ze statusem aby w pytaniach rozstrzygnięcia, chcę jeszcze odnotować, że nie ze wszystkimi strukturami o tym kształcie jest ono kompatybilne. Nie wchodzą tu przede wszystkim w grę pytania retoryczne, których nadawca, zabiegając o uzyskanie prawdziwych zdań na temat odpowiedniego datum quaestionis, jeszcze dodatkowo dorzuca od siebie coś, co wchodzi w semantyczną kolizję z wyrażeniem czy aby_._Zob. np.:

(3) ${ }^{*} C z y(\dot{z})$ aby ten widok nie jest piękny?!

Można by tę rzecz jednocześnie doprecyzować i uogólnić, stwierdzając, że w pytaniach z $a b y$, nie ma prawa pojawić się żaden element modalny, który odnosiłby się bezpośrednio do operatora pytajnego, będącego synkretycznym wykładnikiem rematu, por. np.:

(4) *Czyżby kryzys aby z miesiaca na miesiac się nie pogtębiat? vs. ?Czyżby trwało to aby tylko godzine, a nie, jak zwykle, pót dnia?

(5) *Mialżeby to być aby odpowiedni moment na zmiany? vs. ?Miatżeby król myśleć o połowie aby swoich poddanych, a nie, jak powinien, o wszystkich?

Ta obserwacja nie rozstrzyga rozważanej przeze mnie sprawy, bo rozmaite operatory trybu mogą kolidować zarówno z językowo niezależnym $a b y$, jak i ze zleksykalizowanym pytaniem zawierającym tę cząstkę.

Gdybym problem związany z charakterem aby miała rozwikłać, myśląc o wcześniejszych stanach języka polskiego, np. tych zarejestrowanych w Stowniku staropolskim, Słowniku polszczyzny XVI wieku, w opracowa- 
niach Lindego czy Kryńskiego i Niedźwiedzkiego, to nie wahałabym się powiedzieć, że aby dawało się w poprzednich okresach rozwoju polszczyzny odseparować od reszty wypowiedzenia, że pojawiało się ono w tym samym znaczeniu w bardzo licznych kontekstach z udziałem zdań deklaratywnych, rozkazujących, pytających i wykrzyknikowych. Oto najciekawsze przykłady użyć aby zakwalifikowanych zarówno jako partykułowe, jak i spójnikowe:

(6) Proszę cię aby mnie nie męcz. (Murzyn.)

(7) Owa niegdy aby jedli / Za stot oba byli siedli. (Biernat)

(8) Miły bracie aby wiedziat: twej sięja przyjaźni wstydzę. (Biernat)

(9) İ́ jeślić powiedam ziemskie rzeczy a nie rozumiesz [...] a cożbychci powiadał niebieskie abyś mógt zrozumieć? (Rej)

(10) [pożądliwość] nie jest wtaśnie grzechem / ani jest zakazana przykazaniem: jedno aby nie krolowała w nas / a my żebyśmy jej postuszni nie byli. (Wujek)

(11) Niewiem aby co dziwniejszego na świecie być mogło. (Górnicki)

(12) A ktoby nie robit / aby też taki nie jadt. (Modrzewski)

(13) Panie, nigdy się Ciebie nie zapre, aby mi też umrzeć z Tobq. (Opec)

(14) Dzięki opatrzności, że aby przecie teraz potrafimy zachować powagę naszę. (Kołłąaj).

(15) Miejcie jeszcze cierpliwość aby do roku.

(16) Zabaw się aby przez godzinę.

(17) Aby raz spojrzyj na mnie.

(18) Daj mu aby z czego żyć.

(19) Chory wypił aby tyżkę bulionu.

(20) Starzec aby się uśmiechnat, nic więcej nie powiedziat.

(21) Gdzie aby stanat, zaraz w tym miejscu wyrastaly kwiaty.

(22) Kto aby żyw chwytat za broń $i$ szedt do powstania.

(23) Jestem w obawie, czy aby wszystko przygotowane.

Nad tymi historycznymi kontekstami nie będę się dłużej zatrzymywać. Chcę o nich mówić w innym miejscu w gronie historyków języka. Tu jednak odnotuję rzecz istotną dla dalszego wywodu. Otóż, wszystko wskazuje na to, że $a b y$, o jakie chodzi, było w przeszłości polszczyzny wszędobylską partykułą. Materiał najstarszy potwierdza hipotezę Jadwigi Wajszczuk (1997), że partykuły stoją w jednym domu ze spójnikami i wyrażeniami spójnikopo- 
dobnymi, że - co więcej - granica między nimi jest płynna, bo panuje na niej w perspektywie diachronicznej stały ruch: partykuły się koniunktywizują, a spójniki (wtórnie) wchodzą w funkcje partykuł. Świadczą o tym dobitnie niejednoznaczne konteksty najstarsze od (6) do (13). Z kolei te od (10) do (19) pokazują szerokie spektrum dystrybucyjne interesującego nas elementu, możliwość jego połączeń z wyrażeniami należącymi do różnych klas części mowy w strukturach zróżnicowanych jednocześnie pod względem składniowym. Są wśród nich również rozważane tu zależne i niezależne pytania rozstrzygnięcia, por. przykład (23).

Jak sytuacja przedstawia się we współczesnym języku polskim?

Po pierwsze, odnotujmy, że elementowi aby w pytaniach niezależnych wcale nie musi towarzyszyć partykuła $c z y, n p .:$

(24) (A) zamknat aby drzwi?

Nie przesądza to jeszcze, że element ten da się odseparować od struktury pytajnej. W konstrukcjach wskazanego typu czy bywa pomijane, bo podstawowym wykładnikiem pytania rozstrzygnięcia jest szczególnego rodzaju kontur intonacyjny. Jeśliby więc utrzymywać, że w analizowanych przykładach aby nie może być oderwane od pytania, to trzeba by uściślić, że jest ono nie tyle związane z $c z y$, ile z interrogatywną prozodią. Mówienie o związku frazeologicznym przybierającym kształt $c z y$ aby wydaje się w tej sytuacji nietrafne.

Po drugie, trzeba zauważyć, że interesujące nas aby może być z pytania rozstrzygnięcia wypreparowane bez najmniejszej szkody dla tej struktury, Por.

(25) Czy aby Maciej mi przytaknie? vs. Czy Maciej mi przytaknie?

Nie można więc wykluczyć, że zobiektywizowane pytania rozstrzygnięcia są operandami dla niezależnie od nich funkcjonującego aby. Podobny sprawdzian dla zestawienia wartości może i może by _ w pytaniach typu Może byś kupił po drodze bułki? zastosował A. Bogusławski (2003: 14-16).

Po trzecie, kiedy tymczasowo odsuniemy na bok aby powszechnie uznawane za spójnikowe, takie jak np. użyte w zdaniach (26)-(27): 
(26) Zrobil to, aby sobie udowodnić, że nie jest już uzależniony od nałogu.

(27) Dziecko otworzyło oczy, aby za chwilę znowu zasnqć.,

a także takie, które jest stylistycznym wariantem żeby stanowiącego niezbywalną część większych całości, np.:

(28) Ze wszystkich sit pragnęła, aby w rodzinie zapanowat wreszcie pokój.,

to okaże się, że istnieje co najmniej jeden typ kontekstów, w których aby wprowadza zmianę analogiczną do tej, jakiej podlegają pytania rozstrzygnięcia. Porównajmy w parach następujące przykłady:

(29) Nie zapomnijcie o imieninach mamy. vs. Nie zapomnijcie aby o imieninach mamy.

(30) Żebym z tego wszystkiego nie spóźniła się na samolot. vs. Żebym z tego wszystkiego nie spóźnita się aby na samolot.

Nieprzypadkowo chodzi tu, jak widać, o zdania rozkazujące i optatywne, w których - podobnie, jak w pytaniach, pierwiastki wolitywne mają charakter rematyczny.

Jeśli nie dać się zaczarować takim dokonywanym ad hoc skojarzeniom, jak np. 'wątpienie' czy 'przygana', wiązane z rozważanymi pytaniami w Innym słowniku języka polskiego, to nie można nie wychwycić uderzającej tożsamości różnic w następujących układach:

(31) Czy nie zapomnicie o imieninach mamy? : Czy aby nie zapomnicie o imieninach mamy? :: Nie zapomnijcie o imieninach mamy! : Nie zapomnijcie aby o imieninach mamy!

(32) Czy z tego wszystkiego nie spóźnię się na samolot?: Czy aby z tego wszystkiego nie spóźnię się na samolot?:: Żebym z tego wszystkiego nie spóźniła się na samolot... : Żebym z tego wszystkiego nie spóźniła się aby na samolot...

Te proporcje pokazują, że aby może być nie tylko oderwane od pytania rozstrzygnięcia, ale - co więcej - z takim samym ładunkiem pojęciowym uczestniczy w kontekstach rozkaźnikowych i optatywnych. 
Gdyby nie trzymać się dalej kurczowo takich przybliżeń, jak obawa czy troska mówiącego o zachodzenie odpowiedniego stanu rzeczy, to można by pytać, czy i w innych przykładach nie występuje aby (!) ta sama porcja sensu, która modyfikuje znaczenia zdań w kontekstach (29)-(30):

(33) Odgarnijcie aby zewnętrzna warstwę liści.

(34) Napisz, proszę, aby parę stów!

(35) Niech aby podtoge zamiecie.

(36) Babcia po tym lekarstwie tylko aby spała $i$ spała.

(37) Aby zaczqć, potem już pójdzie.

(38) Aby do rana, aby przeczekać tę straszna noc.

(39) Aby starzec przeżyt marzec!

(40) Okna nieważne. Aby tylko dokładnie zamknat za sobq drzwi!

(41) Pisata te sprawozdania, aby szybciej.

(42) Żyje sięjakoś, aby dalej.

(43) Aby tylko który wychylit głowe z okopu, już go ustrzelili.

(44) Aby tylko się odwrócić, zaraz zaczynaja rozmawiać.

(45) Aby czasem nie zdeptali tulipanów.

(46) Aby bodaj zdat maturę!

(47) Oby zaliczyt aby na trójkę.

Struktury reprezentowane w przykładach od (33) do (36) stanowią swoistą arkę przymierza między dawnymi a nowymi laty, bo choć młodszym użytkownikom polszczyzny mogą się wydać nieco archaiczne, starsze pokolenie ma je w swoich czynnych bądź przynajmniej biernych zasobach językowych. Konteksty (37)-(47) są w pełni naturalne również dla młodszych pokoleń Polaków.

Myli się, jak sądzę, P. Müldner-Nieckowski, który w swoim Wielkim słowniku frazeologicznym (2003), wyodrębnia kilkanaście idiomów z udziałem aby; obok czy aby_, również takie m.in. jak: aby do pierwszego, aby do jutra, aby do wiosny, aby dalej, aby szybciej, aby tylko, aby czasem nie_. Moim zdaniem są to konstrukcje, w których występuje zawsze ten sam element, należący, jak można przypuszczać, do podsystemu meta-wyrażeń epistemiczno-wolitywnych. Dwie inne jednostki reprezentujące ten podsystem, a mające formę adwerbialną, to lepiej i koniecznie, którym poświęciłam odrębne 
artykuły (zob. Danielewiczowa 2012, 2012a). Dla aby występującego w kontekstach (28)-(42) trzeba szukać semantycznego uogólnienia.

Od razu wypada powiedzieć, że błędem jest utożsamianie go pod względem znaczenia z tylko oraz innymi bliskoznacznikami (byle, bodaj, choćby, zaledwie, przynajmniej, oby), powszechnie praktykowane w słownikach polszczyzny dawnej i współczesnej. We wszystkich przywołanych wyżej kontekstach tylko może stanąć obok aby, nie tworząc przy tym efektu pleonastyczności; w niektórych notabene rzeczywiście jest ono zaktualizowane. Przykłady (46) i (47) świadczą o tym, że rozważane tu słowo nie powinno być też zrównywane znaczeniowo z bodaj czy oby.

A jednak włączenie go do kategorii operatorów „ograniczających” (słowniki mówią tu o partykułach, co wymagałoby odrębnej dyskusji) nie jest pozbawione sensu i ma oparcie w intuicjach użytkowników polszczyzny, bo rzeczywiście każe myśleć o pewnego rodzaju ograniczeniu, a ściślej biorąc samoograniczeniu mówiącego. Moja hipoteza jest taka, że rozważane tu wystąpienia aby są sygnałami wolitywnej ascezy. Jego użycie wiąże się bowiem ze wskazaniem minimalnych warunków koniecznych do zaistnienia pewnego pożądanego przez kogoś (nie zawsze przez aktualnego nadawcę) stanu rzeczy. Ten stan rzeczy nie musi być i najczęściej nie jest precyzowany na powierzchni. Czy taka generalizacja znajduje potwierdzenie w języku i jaki w szczegółach wystrój miałaby mieć reprezentacja sensu, o który chodzi, to już temat na inny artykuł. Na zakończenie powiem tylko, że warunki adekwatności sformułowane w sposób tak ogólny, objęłyby być może również konteksty, w których występuje aby tzw. łączqce, a więc powszechnie uznawane za spójnik np.

(48) Mówi, aby tylko mówić.

Z łatwością można przedstawić jednocześnie argumenty przemawiające za tym, że fałszem jest, iżby aby miało taki sam zakres odniesienia, jak $\dot{z} e b y, \mathrm{i}$ by było jedynie stylistycznie nacechowanym wariantem tego ostatniego. $\mathrm{Z}$ drugiej jednak strony daje do myślenia fakt, że tylko w kontekstach opisywanych zwykle jako spójnikowe, aby jest wymienialne z nacechowanym ażeby. Interesujące nas użycia metapredykatywne czy partykułowe takiej substytucji pod groźbą powołania do istnienia konstrukcji anomalnych nie podlegają. Może więc będzie trzeba się poddać i widzieć w polszczyźnie 
dwie niezależne jednostki: metapredykat lub wręcz partykułę (bo choć takie aby występuje współcześnie tylko w określonych typach zdań, to jego łączliwość jest bardzo szeroka: Czy aby Adam zamknat drzwi do piwnicy na mocna kłódkę?, Czy Adam zamkną na mocnq kłódkę aby drzwi do piwnicy, Czy Adam zamknat drzwi do piwnicy aby na mocna któdkę?, Czy drzwi do piwnicy zamkną na mocna kłódkę aby Adam?) z jedną prawostronną walencją i spójnik otwierający wokół siebie dwie pozycje semantyczno-składniowe.

\section{Bibliografia}

BogusŁawski A., 2000, Pytanie o iterację podsegmentów jednostek składniowych, Annales Universitatis Mariae Curie Skłodowska XVIII, Sectio F.F., s. 49-57.

BogusŁawski A., 2003, „Może” i „być może”, w: J. Linde-Usiekniewicz, R. Huszcza (red.), Prace językoznawcze dedykowane Profesor Jadwidze Sambor, Warszawa: Wyd. Wydziału Polonistyki UW, s. 11-43.

Danielewiczowa M., 2012, Koniecznie - niekoniecznie. Przypadek językowej asymetrii, w: D. Zdunkiewicz-Jedynak (red.), Słowa i ich opis. Na drogach wspótczesnej leksykologii, Warszawa: Wydział Polonistyki UW, s. 151-160.

Danielewiczowa M., 2012a, Wokół polskiego wyrażenia lepiej, w: A. Mikołajczuk, K. Waszakowa (red.), Odkrywanie znaczeń w języku, Warszawa: Wyd. Uniwersytetu Warszawskiego, s. 49-58.

Grochowsкi M., 1984, Składnia wyrażeń polipredykatywnych, w: Z. Topolińska (red.) Gramatyka wspótczesnego języka polskiego. Składnia, Warszawa: PWN, s. 271-273.

ISJP - BAŃко M. (red.), 2000, Inny stownik języka polskiego, t. 1-2, Warszawa: Wydawnictwo Naukowe PWN.

Müldner-Nieckowski P., 2003, Wielki stownik frazeologiczny, Warszawa: Wydawnictwo Bettelsman-Media, Świat Książki.

SJPDor - Doroszewski W. (red.), 1958 - 1969, Stownik języka polskiego, t. 1-11, Warszawa: Państwowe Wydawnictwo „Wiedza Powszechna”, Państwowe Wydawnictwo Naukowe.

SWJPDun - Dunaj B. (red.), 1996, Słownik współczesnego języka polskiego, Warszawa: Wilga.

SJPWarsz - Kareowicz J., Kryński A., Niedźwiedzki W. K., 1952: Słownik języka polskiego, Warszawa: PIW (I wyd. Warszawa 1912: Kasa im. Mianowskiego).

SJPLinde - Linde S. B., 1951, Stownik języka polskiego, Warszawa: PWN (I wyd. Lwów 1858: Ossol.).

SStarop - URBAŃcZYk S. (red.), 1973, Stownik staropolski, t. 1, Wrocław: Ossolineum. 
Wajszczun J., 1997, System znaczeń w obszarze spójników polskich. Wprowadzenie do opisu, Warszawa: Katedra Lingwistyki Formalnej UW.

\section{Czy aby Maciej mi przytaknie?}

\section{About the status of the $a b y$ in yes/no questions}

\section{( s u m mary)}

The subject-matter of this article is the status of the expression $a b y$ in the semantic structure of yes/no questions. Two possible solutions to the problem emerge from available lexicographic approaches: in some dictionaries the word $a b y$ is considered to be an inseparable part of an idiomatic interrogative form, while in others it is described as a bilateral, semantically independent unit of language. The author shows that in the past the word in question was a particle having a very wide range of use. In contemporary Polish its distribution is restricted to volitional contexts, but it still satisfies the condition of proportionality; therefore it should be interpreted as a lexical unit of Polish. 